\title{
The Effects of Argumentation Implementation on Environmental Education Self Efficacy Beliefs and Perspectives According to Environmental Problems
}

\author{
Pınar Fettahlığlu \\ Correspondence: Pınar Fettahlıoğlu, Cukurova University Education Faculty Science Education Department, Turkey.
}

Received: January 12, 2018

Accepted: March 15, 2018

Online Published: March 23, 2018

doi:10.11114/jets.v6i4.2925

URL: https://doi.org/10.11114/jets.v6i4.2925

\begin{abstract}
The purpose of this study is to investigate the effect of argumentation implementation applied in the environmental science course on science teacher candidates' environmental education self-efficacy beliefs and perspectives according to environmental problems. In this mixed method research study, convergent parallel design was utilized. Quantitative part of this study was based upon one group pretest-posttest design. Qualitative part of this study was based upon holistic case study. The sample of the study consisted of $263^{\text {rd }}$ year science teacher candidates in A State University Education Faculty Science Education Department in the spring term of 2013-2014 academic years. The data collection tools were environmental education self-efficacy beliefs scale developed by Ozdemir, Aydın and Vural (2009) and drawings drawn by science teacher candidates to determine their perspectives on environmental problems. The experimental study took 7 weeks ( 21 hours). The first week involved the acquaintance with the students and briefing them about the study. Also, in this week, an educational plan related to the argumentation implementation was prepared and applied. And this week finally, scales were administered as pretest. The study started in the second week. The study took five weeks as three hours a week. Last week scales were administered as posttest. In quantitative data analysis paired samples t-test was used. For the analysis of qualitative data, categorical analysis technique, one of the content analysis techniques, was used. At the end of the study, it was observed that the science teacher candidates' self-efficacy beliefs according to environmental education statistically differed in favor of the post-test. In addition, it was also found that, at the end of the study, science teacher candidates' perceptions of environmental problems differed according to their self-efficacy beliefs.
\end{abstract}

Keywords: argumentation, teacher education, environmental education, self-efficacy

\section{Introduction}

Today, environmental problems emerging with industrialization such as global warming, ozone depletion, air and soil pollution, soil erosion and deforestation, depletion of species adversely affect the global ecosystem (Alniaçık \& Koç, 2009; IPCC, 2014). The main reason of this situation is that people unconsciously use their environment for the sake of their own interests (Newell \& Dale, 2015; Yin, Mizokami, \& Aikawa, 2015). Because the main cause of environmental degradation is to try to obtain the energy necessary to eliminate the ever-increasing human needs (Saidi \& Hammami, 2015). Also the fifth evaluation report submitted by the Intergovernmental Panel on Climate Change (IPCC, 2014) outlined the reasons for this situation. According to this report, the amount of carbon dioxide in the atmosphere has steadily increased in recent years; also in recent times this amount has reached unprecedented levels. The IPCC estimates that this problem will cause an increase in temperature of about 5 Fahrenheit in this century. Also, according to the IPCC, this increase can cause radical changes in the regional climate in the world (IPCC, 2014). Climate change is an important detail for life. Extreme weather, floods, thunderstorms and other climate change related events have adverse effects on human health directly and indirectly (McMichael, Woodruff, \& Hales, 2006). In addition, the impact of climate change can even be fatal on living things. Because, as a consequence of flooding and drought, fresh water resources are damaged in surface or underground waters, which leads to the problem of drinking water. Therefore, people are actually harming their environmental by disturbing the nature of environmental in order to live more comfortably (IPCC, 2014). In this context what needs to be done is that people should learn their responsibilities related to the environment in order to resolve environmental problems (Altın, Bacanlı \&Yıldız, 2002; Özer, 1991; Orr, 1994). That is, people should be familiar with environmental issues, understand the system of environment and protect it 
(Yıldız, Sipahioğlu \& Yılmaz, 2005). People also have to cooperate and work with other people to improve the quality and sustainability of their social and natural environment. One of the most effective factors in training individuals for environmental awareness is the environmental education (Sauve, 1996). The purpose of the environmental education is to give them the knowledge, emotion, skills and values necessary to work effectively with each other for sustainability of environment (Fien, 1993). These emphasized skills, knowledge, emotions and skills are now expressed in the concept of environmental literacy. Environmental literacy is the capacity of the individual to show information about the environment as behavior (Roth, 1992). Dinsinger and Roth (1992) stated that an environmental literate person must be a person who can not only have a broad environmental knowledge but also use environmental behavior, beliefs, opinions and attitudes in the detection and prevention of environmental problems. From these expressions, it can be said that an environmental literate person is able to produce critical thoughts about the environmental events. Also environmental literate person is able to research and inquire in this direction. In this context, environmental literacy leads to the formation of nature consciousness in the individual, guiding the individual to learn the laws of nature and to communicate with nature in this direction. In addition, the individual is sensitive to environmental problems and is seeking solutions (Roth, 1992). In fact, in environmental education, individuals acquire the knowledge, skills, attitudes and values they need in order to ensure a sustainable development both locally and globally. So, both this situation and sustainable development are at the center of environmental education (Dimitriou \& Christidou, 2007; Georgopoulos et al., 2011; Kalogiannakis \& Papadakis, 2017).

Within the context of their stated aims, environmental education is included in the most courses (social studies, life science, science and technology lessons) since it is related to all courses in the education system. In this context, after the science curriculum in elementary education changes made in 2005 in Turkey, environmental education has taken place in science program as a spiral. Only the changes made in the education system are not enough to achieve the intended purpose of environmental education. In addition, teachers must have sufficient knowledge, skills and experience in environmental education. Because the teaching programs, methods and techniques can be applied effectively with the knowledge and skill of the teacher, the student item is also affected by the teacher's affective characteristics towards the lesson. For this reason, it is necessary for the teacher to have a deep perspective on environmental problems as well as to develop the cognitive aspects of teaching and instruction (Sözer, 1991). One of these features is self-efficacy belief in environmental education.

The concept of self-efficacy belief, which is the key concept of Albert Bandura's Social Cognitive Theory is defined as "individuals are judged on their own capacities when they perform a certain performance, and their confidence in their ability to do a job, their ability" (Bandura, 1994, p.2). Teacher self-efficacy belief is generally defined as "teachers will demonstrate the necessary behaviors to successfully fulfill the teaching function" (Atıc1, 2000). Self-efficacy belief affects behavior in two different factors. These factors are personal self-efficacy and outcome expectation. The personal self-efficacy sub-dimension is expressed as self-belief that the teacher can demonstrate behavior. The outcome expectation is expressed as beliefs about the extent to which a number of occupational behaviors may cause certain outcomes (Bandura, 1994). In this context, teachers with different personal self-efficacy tend to different behaviors which lead to different outcome expectancies. These different beliefs influence the behavior of the teacher in the educational environment, and the differences in the teacher's behavior influence the students (the successes of the pupils, their characters and the external influences on the pupils). The students' success, their character, and their reaction to the teacher are also a direct influence on the teacher's self-efficacy belief (Dellinger, Bobbett, Olivier \& Ellett, 2008). Therefore, there are differences in behaviors in favor of teachers who have high teacher self-efficacy beliefs between teachers who have a low self-efficacy and a high self-efficacy (Tschannen-Moran \& Hoy, 2001; Tschannen-Moran \& Hoy, 2007; Özkan Tekkaya \& Çakıroğlu., 2002; Yılmaz, Köseoğlu, Gerçek \& Soran, 2004). Self-efficacy belief can also affect the quality and quantity of environmental experiences that teachers present to their students because of the relationship between teachers' beliefs about their abilities and their behavior (Smolleck et al., 2006). For these reasons, it is very important for teachers to have high environmental education self-efficacy beliefs for effective environmental education.

One of the most important places where teachers have knowledge and skills is education faculties where they complete pre-service training. Therefore, in the courses related to environmental education in the education faculties, the teacher candidates should be encouraged to develop both the knowledge related to the environment, emotional characteristics and perspectives on environmental problems. For this purpose, it is necessary to determine teacher candidates' general levels on environmental knowledge, emotional characteristics and perspectives on environmental problems ... etc. And then appropriate methods and techniques should be used in the courses related to the environmental education in order to develop their levels. When literature related to environmental education is examined, it is seen that there are two main models predominantly used in environmental education. These models are explained by Hungerford \&Peyton (1994); Flogaitis \& Agelido (2003) and Kalogiannakis \& Papadakis (2017) in the following way: 
- Multi-scientific model: this model contains teacher-centered instruction strategies, approaches and Environmental Education activities from multiple subject areas such as language arts, mathematics, social studies, science, etc.

- Interdisciplinary Model: This model contains both strategies and methods that promote learner-centered teaching.

From these models, inquiry-based teaching methods and techniques (second of them) supports the development of self-efficacy beliefs of teacher candidates. (Bell et al., 2003; North American Association for Environmental Education [NAAEE], 2010). So, in this way, individuals both get the ability to question the events in their environment and develop self-efficacy beliefs. In this context, argument-based learning, which is frequently discussed recently, may be a suitable model in implementation for effective environmental education.

The argument based learning that has started to be applied in education with the Toulmin model; is expressed as a learning approach in which the reasons for reasoning, evaluating, opposing and supporting the data obtained from experimental or various sources in the social interaction environment are put forward (Jimenez, Alexander \& Pereiro-Munoz, 2002). In an argument-based learning approach, students clearly express the reasons that support their views by using their prior knowledge and try to justify their views. Other students clearly express opposing views, explain doubts and offer alternative ideas (Driver, Asoko, Leach, Mortimer \& Scott, 1994). In this context, discussions of socio-scientific ideas about how to dispose of household waste in lessons; it helps students to develop appropriate skills and appropriate arguments, thinking about appropriate evidence (Newton, Driver \& Osborne, 1999). Therefore, students can develop decision-making skills on a socio-scientific subject by learning how to analyze information with an argument-based learning model (Hogan, 2002). In order for this process to be meaningful, Toulmin (1958) described as a model describing the main points of the scientific debate and showing the relationships between them. This model is given in Figure 1:

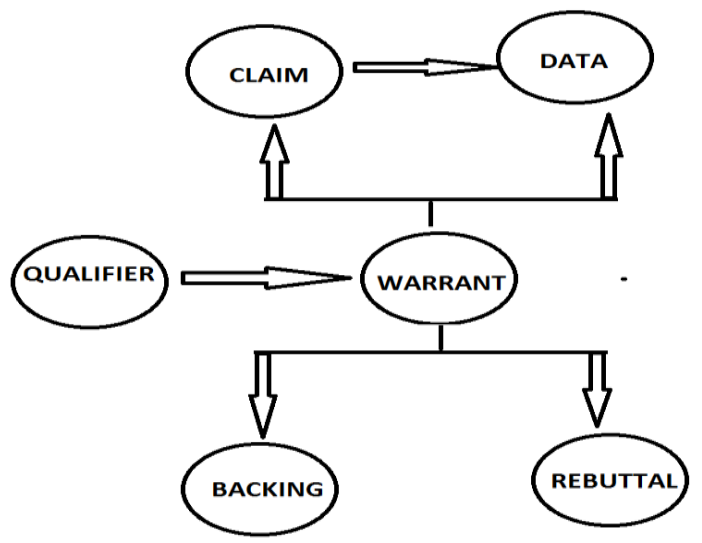

Figure 1. Toulmin argumen model

Descriptions of all the components of Toulmin in the argument model are given below (Jimenez-Aleixandre \& Pereiro-Munoz, 2002, Simon et al., 2006):

Claim; it is the opinion put forward about a subject.

Data; are the various sources of information used to support the viewpoint contained in the claim.

Warrant; statements or principles provide link between the claims and the data.

Qualifier; It is the basic assumptions confirming certain warrants.

Backing; these are the limiting cases in which claims are approved correctly.

Rebuttal; it is the situation that claim is not acceptable

It is seen that courses, in which the argumentation practices are implemented, are generally influential in the development of epistemic beliefs, critical thinking, problem solving skills, scientific process skills and conceptual learning. Argumentation practices also play an important role in structuring the models and theories used to explain socio-scientific issues (Erduran \& Alexandre Jimeneze, 2011). Therefore, it can be said that the argumentation implementation has an important role in the aim of environmental education as in other lessons. However, when the related literature is examined, it has been seen that there is no study investigating the effects of argumentation implementation on environmental education self-efficacy beliefs and the development of an environmental perspective. But one of the necessary skills in teachers is environmental education self-efficacy belief for the effectiveness of this education. However, there are very few studies to determine the environmental education self-efficacy belief in the related literature (Sia, 1992; Çimen et al., 2011). According to the results of this studies, it is seen that teacher 
candidates" environmental education self-efficacy beliefs are low (Sia, 1992). When the studies aiming to improve the teacher candidates' self-efficacy beliefs are examined, it is seen that there is less emphasis on the environmental education self-efficacy beliefs than other teacher self-efficacy beliefs (Nare, 2015; Holden, Groulx, Bloom, \& Weinberg, 2011; Moseley et al., 2002; Moseley, Reinke, \& Bookout,2003; Moseley et al., 2003; Moseley \& Utley, 2008).

In this context the purpose of this study was to investigate the effect of argumentation implementation in the environmental science course on science teacher candidates' environmental education self-efficacy beliefs and perspectives according to environmental problems. Within the scope of this purpose, the following questions were sought:

1. Are there significant differences between the science teacher candidates' pre-test and post-test scores obtaining environmental education self-efficacy belief scale?

2. What are the $3^{\text {rd }}$ year science teacher candidates' perspectives according to environmental problems

a. Before implementing argumentation?

b. After implementing argumentation?

3. Do $3^{\text {rd }}$ year science teacher candidates' perspectives according to environmental problems differ according to their level of environmental education self-efficacy when considering their post-test scores?

\section{Method}

This section presents the participants, briefly sets the context for research, and then elaborates on research design.

\subsection{Research Design}

In this research, mixed method research study, in which convergent parallel design was utilized. This pattern is used to compare the research of quantitative statistical results with qualitative findings and triangulate with other analysis methods in order to support and confirm the process. Also; the convergent parallel pattern was chosen in this study in order to reveal the differences or complementary data about the survey and stronger results (Creswell, 2012)..

Quantitaive part of this study was based upon one group pretest-posttest design. The design of the quantitative portion of the study is summarized in Table 3 (Creswell, 2012).

Table 1. One group pretest-posttest design used in the survey

\begin{tabular}{llll}
\hline G1 & O1.1 & X & 01.2
\end{tabular}

G1: Research group

O1.1: Application of environmental education self-efficacy scale and picture drawing before argumentation implementation

O1.2: Application of environmental education self-efficacy scale and picture drawing after argumentation implementation

$\mathrm{X}$ : Argumentation application

Qualitative part of this study was based upon multiple holistic case designs. Qualitative research method was chosen in order to make an in-depth description of the research and reveal patterns in the research. The case study was chosen since the research focused on revealing the prospective teachers' perspective on the environmental problems. In addition, a single unit of analysis has been dealt with holistically to understand the changes in the relevant situation. In this context; a holistic single case design is used in the qualitative part of this study.

\subsection{Data Collection Tools}

In the study, the environmental education self-efficacy belief scale was used as a data collection tool and drawings drawn by the science teacher candidates were used to determine students' perspectives on environmental problems.

\subsubsection{Environmental Education Self Efficacy Beliefs Scale}

The environmental education self-efficacy belief scale was developed by Özdemir, Aydın \&Vural (2009). The scale has 15 items and four sub dimensions. These are academic competence perception, Responsibility Perception, Instructive Competence Perception, and Guidance Perception. The three items in the list are the negative $(6,9$ and 12) and the others are positive. Scale was prepared in a Likert type $(5=$ totally agree, $4=$ agree, $3=$ Somewhat agree, $2=$ Disagree, $1=$ strongly disagree). When the reliability of the scale is examined The Cronbach $\alpha$ value was 0.79 for the academic competence perception subscale; .86 for responsibility perception subscale; .74 for Instructive Competence Perception and .68 for Guidance Perception. The reliability of the scale was found .76 . 


\subsubsection{Drawing Writing Method}

The drawing-writing technique can be described as a data collection technique, which includes descriptions of drawings generally referred to as handmade (Whitehead \& Mcniff, 2004). The technique of drawing-writing, which is often used to reveal ideas, meanings, feelings, or cognitive structures hidden in the human mind, is considered to be a useful tool to reveals visual image that occurs in the mind (Borthwick, 2011; Kurt, Gökmen \& Ekici, 2013). In the context of the drawing-writing technique, participants were asked to draw drawings of environmental problems. It is also requested from participants to explain what they want to portray in the drawings they draw. In this application 5 minutes were given for the cartoon drawing to participants and 5 minutes were given to write the problems they wanted to describe in the drawings. In Figure 2, examples of drawing-writing technique are presented.

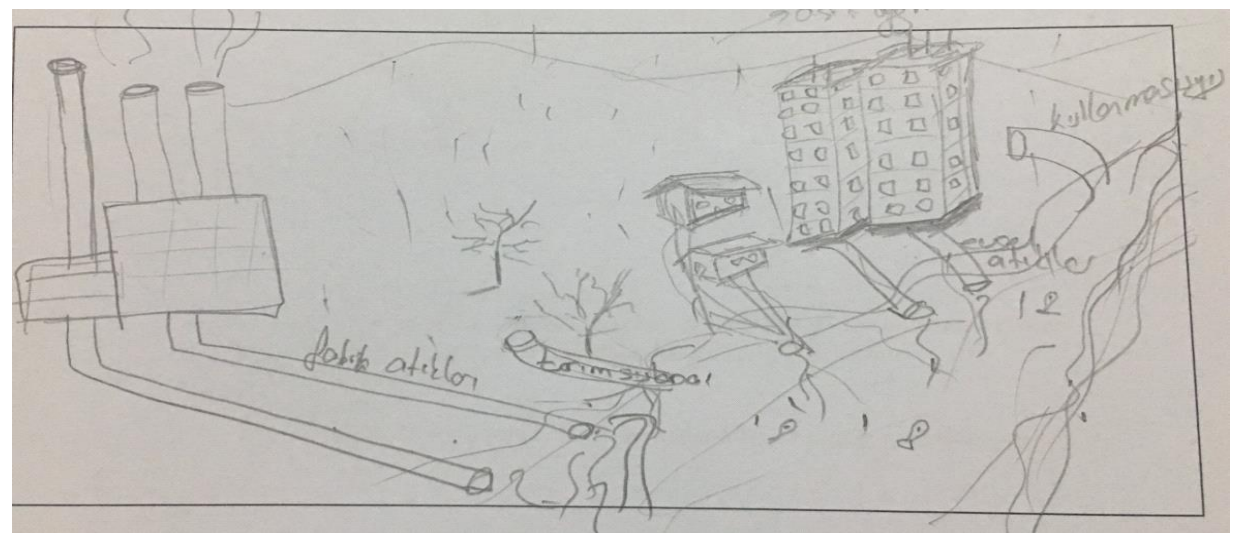

Figure 2. S14's Drawing Example

\subsection{Participants}

The sample of the study was consisting of $263^{\text {rd }}$ year science teacher candidates' in A State University Education Faculty Science Education Department in the spring term of 2013-2014 academic year. Science teacher candidates' personal information is explained in table 2 .

Table 2. Science teacher candidates' personal information

\begin{tabular}{|c|c|c|c|}
\hline \multicolumn{2}{|l|}{ Science teacher candidates' characteristics } & \multirow{2}{*}{$\begin{array}{l}\mathbf{f} \\
21\end{array}$} & \multirow{2}{*}{$\%$} \\
\hline Sex & Female & & \\
\hline & Male & 5 & 23.1 \\
\hline \multirow[t]{5}{*}{ Age range } & $19(1994)$ & 1 & 3.8 \\
\hline & $20(1993)$ & 11 & 42.3 \\
\hline & $21(1992)$ & 8 & 30.8 \\
\hline & $22(1991)$ & 4 & 15.4 \\
\hline & $23(1990)$ & 2 & 7.7 \\
\hline \multirow[t]{3}{*}{ Interest in environmental issues } & Too much & 5 & 19.2 \\
\hline & Enough & 19 & 73.1 \\
\hline & Some & 2 & 7.7 \\
\hline \multirow[t]{4}{*}{ Parent interest in environmental issues } & Too much & 1 & 3.8 \\
\hline & Enough & 14 & 53.8 \\
\hline & Some & 9 & 34.6 \\
\hline & Very little & 2 & 7.7 \\
\hline \multirow{4}{*}{ Location } & Village & 2 & 7.6 \\
\hline & District & 5 & 19.2 \\
\hline & City & 9 & 34.6 \\
\hline & Big city & 10 & 38.5 \\
\hline \multirow{5}{*}{$\begin{array}{l}\text { Communication tool that follows environmental } \\
\text { issues }\end{array}$} & Internet & 21 & 58.3 \\
\hline & Radio and television & 3 & 8.3 \\
\hline & Magazine newspaper & 5 & 13.9 \\
\hline & Social environment & 4 & 11.1 \\
\hline & The work of environmental NGOs & 3 & 8.3 \\
\hline
\end{tabular}


When Table 2 is examined, it is seen that 21 of the teacher candidates are girls; 5 of them are male. Teacher candidates are predominantly $20(42.3 \%)$ years old, and their attention to environmental problems is at an enough level (73.1\%). Parallel to this situation, parents' interest towards the environment is at predominantly an enough level (53.8\%). The childhoods of teacher candidates were mostly in urban areas (38.5\%). Internet was the most used communication tool that they obtain information on environmental problems (58.3\%). The information in Table 1 are the most important external factors affecting the perceptions of prospective teachers. For this reason, it is important to provide this information for research. This information was used to promote the participants. In other analyzes this information is not included.

\subsection{Content of the Study}

This research was carried out at a state university in Turkey. In Turkey, there are two periods for each year: Spring semester and fall semester at universities. This research was carried out in the environmental science course in the spring semester of the $3^{\text {rd }}$ year. The environmental science course is a compulsory course in the education faculty of science teacher education. The aim of this course is to help science teacher candidates to provide knowledge about environmental issues and problems. Within the scope of this aim, the environmental problems issue in the environmental science course were taken into consideration in this research. Argumentation implementation and small group learning methods were used in the course. The class was primarily divided into small groups. Then a video was presented to the teacher candidates as draw attention activities. At the end of the related video, the teacher candidates were asked questions about the subject. Subsequently, discussions were held in the context of these questions and in such a way that the small groups established by adhering to the activity papers were independent of each other. After the small group discussion ended, the big class debate was started. After all the groups suggested their opinions, the teacher ended the lesson by taking the general recap of the accepted cases.

\subsection{Analysis of Datum}

Paired sample t-test was used in the analysis of quantitative data. In the analysis of qualitative data, categorical analysis technique was used. Categorical analysis firstly aims to divide a given message into units and then group these units according to specific criteria (Bilgin, 2006). In this study, the frequencies of the codes were calculated by the researchers, then obtained codes were classified under certain categories. The reliability formula of Miles and Huberman (1994) was taken into account in order to calculate the reliability values of the qualitative data: [Opinion union / (Union union + Dispersion of opinion) x 100]. Two researchers coded drawings at different times independently to determine the consistency of this research. So the average reliability was found to be $82 \%$.

\section{Results}

3.1 Are There Significant Differences Between the Pre-test and Post-test scores of Science Teacher Candidates' Environmental Education Self-Efficacy Beliefs Which Were Exposed to Argumentation Application?

Table 3. Dependent groups t test results of environmental education self-efficacy pre-test and posttest scores

\begin{tabular}{|c|c|c|c|c|c|c|c|}
\hline & & $X$ & $\mathrm{~N}$ & $\mathrm{~S}$ & $\mathrm{df}$ & $\mathrm{t}$ & $\mathrm{P}$ \\
\hline \multirow{2}{*}{$\begin{array}{l}\text { Academic } \\
\text { perception }_{(a)}\end{array}$} & Pretest & 3.3 & 26 & .59 & \multirow[t]{2}{*}{25} & \multirow[t]{2}{*}{3.74} & \multirow[t]{2}{*}{$0.01 *$} \\
\hline & Post test & 3.8 & 26 & .58 & & & \\
\hline \multirow[t]{2}{*}{ Responsibility perception $_{(b)}$} & Pretest & 2.4 & 26 & .76 & \multirow[t]{2}{*}{25} & \multirow[t]{2}{*}{1.67} & \multirow[t]{2}{*}{0.107} \\
\hline & Post test & 2.7 & 26 & .67 & & & \\
\hline \multirow{2}{*}{$\begin{array}{l}\text { Teaching } \\
\text { perception }_{\odot} \\
\end{array}$} & Pretest & 3.1 & 26 & .39 & \multirow[t]{2}{*}{25} & \multirow[t]{2}{*}{2.40} & \multirow[t]{2}{*}{$0.024 *$} \\
\hline & Post test & 3.5 & 26 & .55 & & & \\
\hline \multirow[t]{2}{*}{ Directional perception $_{(\mathrm{d})}$} & Pretest & 2.4 & 26 & .62 & \multirow[t]{2}{*}{25} & \multirow[t]{2}{*}{1.53} & \multirow[t]{2}{*}{0.138} \\
\hline & Post test & 2.3 & 26 & .68 & & & \\
\hline \multirow[t]{2}{*}{ General } & Pretest & 2.8 & 26 & .25 & \multirow[t]{2}{*}{25} & \multirow[t]{2}{*}{2.86} & \multirow[t]{2}{*}{$0.008 *$} \\
\hline & Post test & 3.1 & 26 & .29 & & & \\
\hline
\end{tabular}

$* \mathrm{p}<.0 .05$

When the general and sub-dimensions of the self-efficacy scale for environmental education are examined, it is seen that the science teacher candidates' average scores obtained from the posttest are higher than pre-test scores. Paired sample t-test was used to see if there was a statistically significant difference between these scores. According to the results, it was found that there was a statistically significant difference in favor of post-test scores of science teacher candidates in the general score, academic efficacy sub dimension and teacher perception of competence sub dimension score $\left[\mathrm{t}_{\text {total }}(25)=2.86\right.$, $\left.\mathrm{p}<.05 ; \mathrm{t}_{\mathrm{a}(25)}=3.74, \mathrm{p}<.05 ; \mathrm{t}_{\mathrm{c}(25)}=2.40, \mathrm{p}<.05\right]$. 


\subsection{How Are the Perspectives for Environmental Problems of the $3^{\text {rd }}$ Year Science Teacher Candidates Before and After the Implementation?}

Table 4. Perspectives of science teacher candidates towards environmental problems before and after argumentation implementation

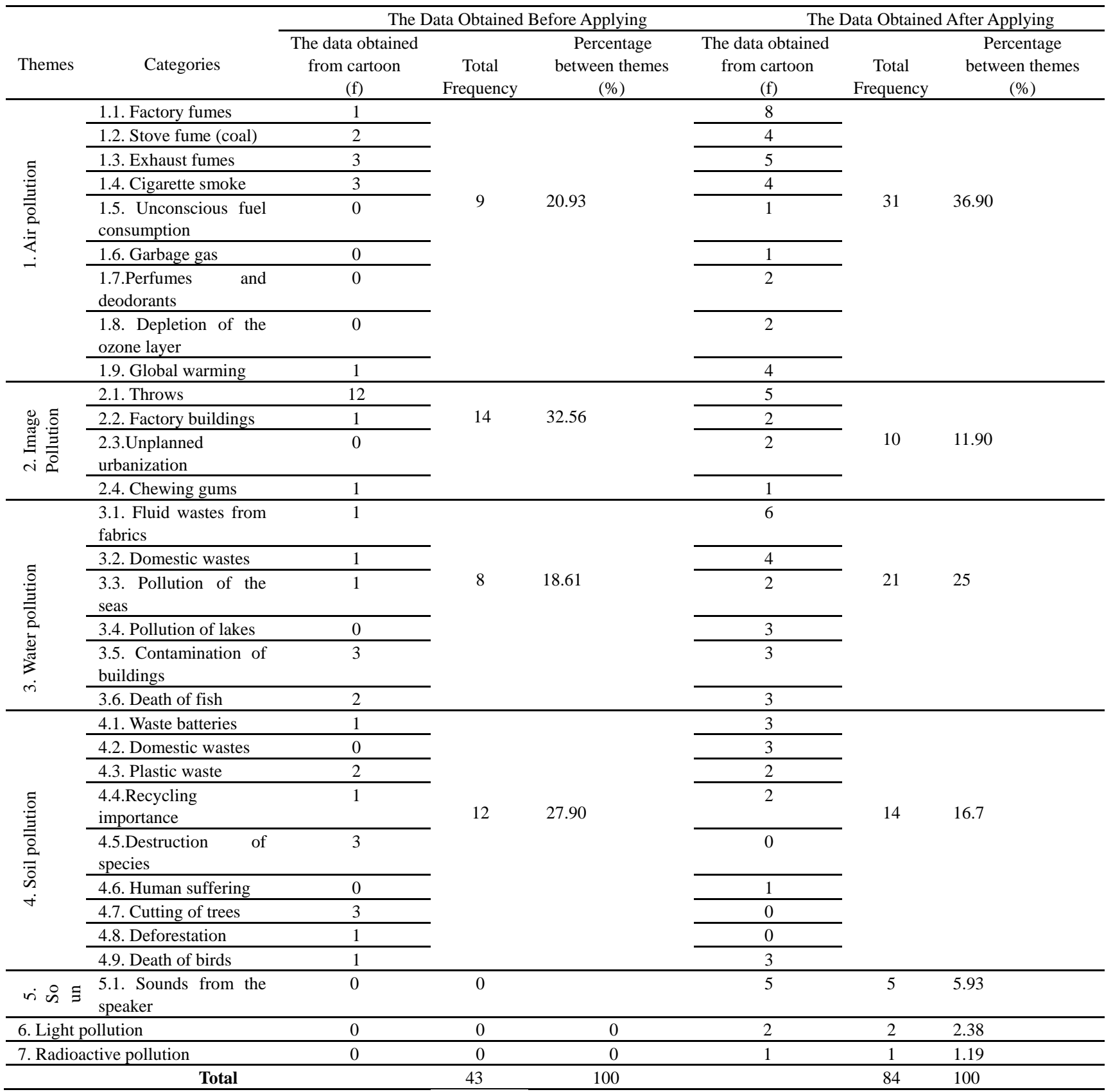

When the drawings drawn by the science teacher candidates before the application are examined, it is seen that the science teacher candidates disturbed from the garbage which are thrown at most. Regarding the subject, student number 9 says, " I feel uncomfortable because the science teacher candidates who will train the future are throwing the garbage to floor". Also student number 26 says "people are throwing rubbish around without any attention. They are ignoring the environmental pollution that occurs. Everyone is throwing away rubbish, so the environmental problem is getting worse." That is, teacher candidates predominantly suggest opinions about image pollution before the application. When these opinions are examined, it is seen that the teacher candidates are most active in the events that they living areas. On the other side, when the environment they are living in is examined, the air pollution in the surrounding environment is also very problematic. However, teacher candidates' views on air pollution are limited. In this case, it can be considered that teacher candidates do not have clear information about air pollution and do not suggest opinion about air pollution. In addition, according to the findings obtained from the research, there are limited points of view on the problems that the 
teacher candidates live directly in their living areas. Teacher candidates are not aware of how the environmental problem in any part of the world will affect them. This is because they do not have a clear accumulation of knowledge. This situation causes that the teacher candidates can not to see, understand and interpret the environmental problems.

When the responses given at the end of the study were examined, it was determined that science teacher candidates especially reported opinions on air pollution (factory smoke) and water pollution (factory liquid waste). Regarding the subject, science teacher candidate number 7 says "Their living beings are particularly affected by industrialization wastes. There are even deaths. It is important for everybody that life goes away. Everyone should be sensitive to this ". Also science teacher candidate 17 says "I wanted to tell you that the harmful gases from the factory caused air pollution and that harmful chemical wastes were thrown into the water. Harmful gases thrive on the ozone layer and sunlight damages people According to the results obtained from the research, the science teacher candidates want to draw much attention to the air pollution which is in their mostly living areas. According to these results, it can be said that teacher candidates have the ability to analyze the situations in their environment and to interpret the environmental problems that they are experiencing. In addition, science teacher candidates also emphasized the ozone layer's thinning, sound, light and radioactive pollution. Teacher candidates are also able to express their discomfort.

3.3 Does $3^{\text {rd }}$ Year Science Teacher Candidates' Perspectives According to Environmental Issues Differ According to Their Level of Environmental Education Self-Efficacy When Considering Their Post-Test Scores?

The environmental education self-efficacy levels of the science teacher candidates are grouped at the lower, middle and upper levels using arithmetic average and standard deviation values. The findings are given in Table 4.

Table 5. Self-efficacy belief levels for environmental education of third year science teacher candidates

\begin{tabular}{|c|c|c|c|c|c|c|}
\hline Name of the group & Self-efficacy scores & $\mathrm{f}$ & $\%$ & $X$ & $\mathrm{t}$ & $\mathrm{S}$ \\
\hline low & $1>X \leq 2.81$ & 4 & 15.38 & \multirow{3}{*}{3.1} & \multirow{3}{*}{3.06} & \multirow{3}{*}{.29} \\
\hline Medium & $2.81<\mathrm{X} \leq 3.39$ & 17 & 65.38 & & & \\
\hline High & $3.39>X>5.0$ & 5 & 19.23 & & & \\
\hline
\end{tabular}

When Table 5 is examined, the number of science teacher candidates at lower level is 4 ; intermediate level 17; it seems that there are 5 at the top level. It can be said that $81 \%$ of science teacher candidates in the bottom and middle level. So, it can be said that science teacher candidates' self-efficacy beliefs are not a competent level.

Science teacher candidates' perspectives about environmental problems according to their self-efficacy beliefs are given in Table 6.

When Table 6 is examined, it is determined that science teacher candidates with a low level of environmental education self-efficacy beliefs are predominantly informed about the disposals. Science teacher candidates with moderate and high self-efficacy beliefs have reported opinions on exhaust fumes and factory wastes. Teacher candidate's Environmental education self-efficacy with low beliefs focus on the environmental problems they have seen. Environmental education self-efficacy beliefs medium and high-level teacher candidates focus on the effects that cause environmental problems. In this context, it can be said that environmental education self-efficacy belief affects the ability to see, perceive and interpret negative situations in the environment. 
Table 6. Analysis of the drawings of the science teacher candidates at the end of the implementation according to their self-efficacy beliefs levels

\begin{tabular}{|c|c|c|c|c|c|c|c|c|c|c|c|c|}
\hline \multirow{4}{*}{$\sum_{=1}^{\infty}$} & \multirow{4}{*}{ 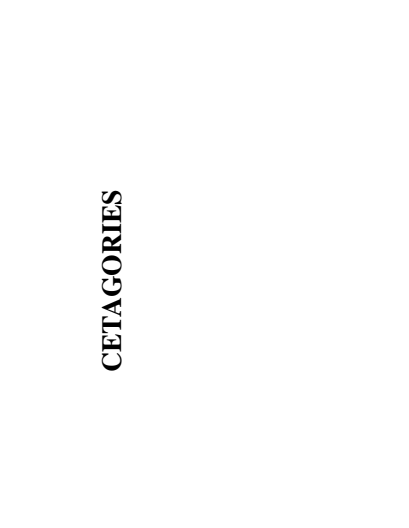 } & \multicolumn{9}{|c|}{ Self-Efficacy Beliefs Scores Levels } & \multirow{3}{*}{\multicolumn{2}{|c|}{ हूँ }} \\
\hline & & \multirow{3}{*}{ 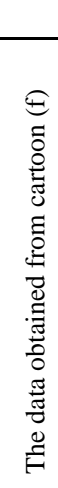 } & \multicolumn{2}{|c|}{ Low level } & \multicolumn{3}{|c|}{ Medium level } & \multicolumn{3}{|c|}{ High level } & & \\
\hline & & & \multirow[t]{2}{*}{ 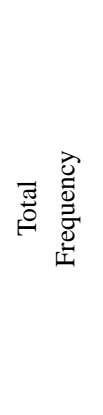 } & \multirow{2}{*}{ 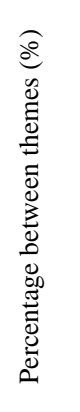 } & \multirow{2}{*}{ 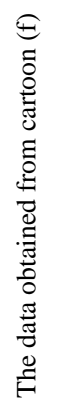 } & \multirow[t]{2}{*}{ 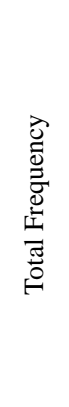 } & \multirow{2}{*}{ 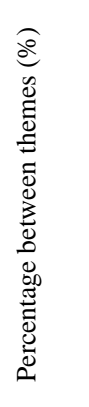 } & \multirow{2}{*}{ 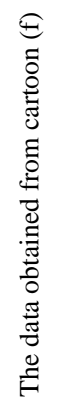 } & \multirow[t]{2}{*}{ 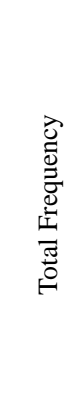 } & \multirow{2}{*}{ 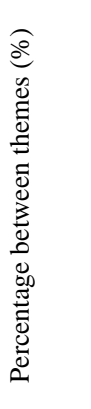 } & & \\
\hline & & & & & & & & & & & f & $\%$ \\
\hline \multirow{9}{*}{ 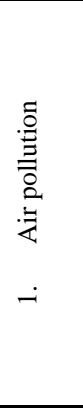 } & 1.1Factory fumes & 2 & \multirow{9}{*}{5} & \multirow{9}{*}{5.95} & 3 & \multirow{9}{*}{14} & \multirow{9}{*}{16.66} & 3 & \multirow{9}{*}{12} & \multirow{9}{*}{14.28} & \multirow{9}{*}{31} & \multirow{9}{*}{36.9} \\
\hline & 1.2.Stovefume (coal) & 0 & & & 2 & & & 2 & & & & \\
\hline & 1.3.Exhaust fumes & 1 & & & 2 & & & 2 & & & & \\
\hline & 1.4.Cigarette smoke & 1 & & & 2 & & & 1 & & & & \\
\hline & $\begin{array}{ll}\begin{array}{l}\text { 1.5.Unconscious } \\
\text { consumption }\end{array} & \text { fuel } \\
\end{array}$ & 0 & & & 1 & & & 0 & & & & \\
\hline & 1.6. Garbage gas & 0 & & & 1 & & & 0 & & & & \\
\hline & 1.7.Perfumes and deodorants & 0 & & & 0 & & & 2 & & & & \\
\hline & 1.8. Depletion of the ozone layer & 0 & & & 1 & & & 1 & & & & \\
\hline & 1.9.Global warming & 1 & & & 2 & & & 1 & & & & \\
\hline & 2.1. Throws & 2 & & & 2 & & & 1 & & & & \\
\hline 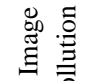 & 2.2.Factory buildings & 0 & 2 & 2.38 & 0 & 3 & 3.57 & 2 & 5 & 5.95 & 10 & 11.9 \\
\hline & 2.3.Unplanned urbanization & 0 & & & 1 & & & 1 & & & & \\
\hline & 2.4. Chewing gums & 0 & & & 0 & & & 1 & & & & \\
\hline & 3.1.Fluid wastes from fabrics & 1 & & & 3 & & & 2 & & & & \\
\hline & 3.2. Domestic wastes & 0 & & & 2 & & & 2 & & & & \\
\hline$\stackrel{\bar{\Xi}}{\circ}$ & 3.3.Pollution of the seas & 0 & & & 2 & & & 0 & & & & \\
\hline 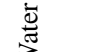 & 3.4.Pollution of lakes & 0 & 1 & 1.19 & 2 & 11 & 13.09 & 1 & 9 & 10.71 & 21 & 25 \\
\hline 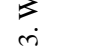 & 3.5.Contamination of buildings & 0 & & & 1 & & & 2 & & & & \\
\hline & 3.6.Death of fish & 0 & & & 1 & & & 2 & & & & \\
\hline & 4.1.Death of fish & 0 & & & 2 & & & 1 & & & & \\
\hline & 4.2. Waste batteries & 1 & & & 1 & & & 1 & & & & \\
\hline & 4.3.Domestic wastes & 0 & & & 1 & & & 1 & & & & \\
\hline & 4.4.Plastic waste & 0 & 1 & 1.19 & 2 & 7 & 8.35 & 0 & 6 & 7.15 & 14 & 16.7 \\
\hline 哥 & 4.5.Recycling importance & 0 & & & 0 & & & 1 & & & & \\
\hline$\stackrel{2}{2}$ & 4.6.Destruction of species & 0 & & & 0 & & & 0 & & & & \\
\hline$\overline{\overline{0}}$ & 4.7.Human suffering & 0 & & & 0 & & & 0 & & & & \\
\hline$\dot{q}$ & 4.8. Cutting of trees & 0 & & & 1 & & & 2 & & & & \\
\hline 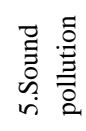 & 5.1.Deforestation & 0 & 0 & 0 & 2 & 2 & 2.37 & 3 & 3 & 3.56 & 5 & 5.93 \\
\hline 6. Ligh & pollution & 0 & 0 & 0 & 1 & 1 & 1.19 & 1 & 1 & 1.19 & 2 & 2.38 \\
\hline 7. Radi & oactive pollution & 0 & 0 & 0 & 0 & 0 & 0 & 1 & 1 & 1.19 & 1 & 1.19 \\
\hline & Total & & 9 & $\begin{array}{c}10.7 \\
1\end{array}$ & & 38 & 46.04 & & 37 & 44.03 & 84 & 100 \\
\hline
\end{tabular}




\section{Discussion}

A qualified teacher is an individual who has profound and extensive content knowledge, pedagogical knowledge and skill to develop the student's achievement. In this context, effective environmental education activities should be applied for science teacher candidates during their pre-service training for a better environmental education (Özdemir, 2003). In this context the purpose of this study was to investigate the effect of argumentation implementation in the environmental science course on science teacher candidates' environmental education self-efficacy beliefs and perspectives according to environmental problems. At the end of the research, it was determined that the science teacher candidates' environmental education self-efficacy beliefs, academic efficacy sub dimension and teacher perception of competence sub dimension improved. Also it was found that science teacher candidates' responsibility perception and directional perception (sub dimension of the environmental education self-efficacy beliefs) did not improve in this study.

Environmental education self-efficacy belief can be defined as teachers' beliefs about their ability to effectively teach this education. The development of these skills is crucial in achieving the objectives of environmental education in educational programs. When studies on environmental education are examined, it has been determined that the teachers' self-efficacy beliefs about environmental education have an effect on the effort they have shown in the course, the targets they set for the students and the planning of courses for environmental education (Tschannen-Moran \& Hoy, 2001). So, implementations supporting the development of teachers' and prospective teachers' environmental education self-efficacy beliefs is very important for an effective environmental education. Also Sia (1992) found that teacher candidates realize that effective teaching can increase students' perspectives on Environmental Education. When the related literature is investigated, it is seen that inquiry based learning environment supports development of this beliefs (Greer, Richardson, Ling, Liang \& Donna, 2014).

In this study, it was found that there was also no improvement in the responsibility perception and guidance perception dimensions of the environmental education self-efficacy beliefs scale. The perception of responsibility is the responsibility of the person to fulfill obligations to himself and others in a timely manner. Responsibility is one of the most important items of character. The responsible person must fulfill his / her duties and functions on time and in the desired manner. The sense of responsibility lies naturally within a person at a young age, or it can then be created through external training. However, for the development of sense of responsibility, practical tasks should be given to individuals (Bandura, 1997; Ekici, 2014; Kurt \& Ekici, 2013). Teacher's sense of responsibility affects classroom management skills. Also this sense is affected their classroom management skills. Many research findings on this area highlight that teacher competence is s directly related to the skills and approaches they use in classroom management (Henson, 2001; Savran \& Çakıroğlu, 2003; Woolfolk \& Hoy, 1990). The reason for the lack of sense of responsibility for environmental education can be explained by this situation in this study. That is, science teacher candidates were not given a job within the context of environmental education during the implementation period. Practical activities were used in the course, but the course has been conducted under the supervision of the researcher. In other words, science teacher candidates were not given any responsibility for the management of the course. Therefore, this skill did not show improvement in the research.

Another important aspect of the research is that science teacher candidates' guidance perception did not improve. The guidance perception sub-dimension reveals the perception of how an individual can orient both himself or herself and his her students in the future (Özdemir, Aydın \& Vural, 2009). This result shows that the Environmental Science course did not contribute to the acquisition of the guidance perception. As a teacher, the perception of students' acceptance of the responsibility of environmentalist behavior and the perception of competence as a teacher are emerging as perceptions that are expected to develop in favor of students but cannot be improved. Many external factors (living with the natural environment, media, family, activities, experiences, attitudes, information, values, etc.) can naturally affect self-efficacy perception. For this reason, it should be noted that other factors may also be effective in the formation of these differences (Özdemir, Aydın \& Vural, 2009).

According to the findings obtained from the drawings in the research, it was determined that the science teacher candidates expressed the image pollution severely before the implementation, but at the end of the implementation it was seen that they were concerned about air pollution and water pollution. In addition, it was determined that science teacher candidates expressed opinions about noise, light and radioactive contamination. Also, it was observed that environmental problems they express were changed according to the science teacher candidates' self-efficacy beliefs. When examining the science teacher candidates' perception of environmental problems according to environmental education self-efficacy levels, it was observed that low-level teacher candidates disturbed by the trash in their surroundings. The teacher candidates with a middle-level self-efficacy beliefs were also affected by garbage and factory exhaust fumes. Science teacher candidates with a high self-efficacy beliefs expressed that they were affected by household waste, resulting from fish deaths, global warming, and waste pills. This result indicates that as the level of self-efficacy beliefs about environmental education increases, science teacher candidates look more environmentally conscious and see events or problems more clearly. When the related literature is examined, it is seen that individuals' environmental education self-efficacy beliefs level is affect their perspectives on environmental events (Gardner, 2009). 
To sum up, it can be express that the increase in environmental education self-efficacy beliefs affects the perception of environmental problems. For this reason, firstly all teachers and prospective teachers should be encouraged to have environmental education self-efficacy skills. Then trainings should be organized to develop these skills. Because, it is very important to set targets for environmental education in pre-service training and to plan the trainings necessary for the prospective teachers to reach these targets. It is also important to support scientific researches that assesses the impact of planned trainings. Because it is necessary to examine whether the process is implemented as planned. Otherwise, it is not enough to plan how to make the trainings. It is also very important that the planning is put into practice.

\section{References}

Alnıaçı, Ü., \& Koç, F. (2009). Evaluation of the university students' attitudes towards the environment with the new environmental paradigm scale. Balıkesir University Burhaniye Vocational School Regional Development Congress, Burhaniye, Balıkesir, 178-185.

Altın, M., Bacanlı, H., \& Yıldız, K. (2002). Attitudes of biology teacher candidates towards the environment, $V$. National Science and Mathematics Education Congress. 16-18 September 1 2002, ODTÜ, Ankara.

Atıc1, M. (2000). Examining the Primary School Teachers' Role of Competence Expectancy in Classroom Management on a Research Group Selected from the UK and Turkey. http://www.yok.gov.tr/egfak/meral.htm

Bandura, A. (1997). Self efficacy: the exercise of control. W.H. Freeman and Company: New York

Bandura, A. (1997). Self-efficacy: The exercise of control. New York, NY: W. E. Freeman and Co (must be removed)

Bell, C., Shepardson, D., Harbor, J., Klagges, H., Burgess, W., \& Meyer, J. (2003). Enhancing teachers' knowledge and use of inquiry through environmental science education. Journal of Science Teacher Education, 14(1), 49-71. https://doi.org/10.1023/A:1022951523402

Bilgin, N. (2006). Content analysis techniques and case studies in social sciences. Ankara: Siyasal Publishing.

Borthwick, A. (2011). Children's perceptions and attitudes towards their mathematics lessons. In C. Smith, (Ed.), British Society for Research İnto Learning Mathematics, 31, 37-42.

Çimen, O., Gökmen, A. S., Altunsoy, E. G., \& Yılmaz, M. (2011). Analysis of Biology Candidate Teachers' Self Efficacy Beliefs On Environmental Education. Procedia Social and Behavioral Sciences, 15, 2549-2553. https://doi.org/10.1016/j.sbspro.2011.04.143

Creswell, J. W. (2012). Educational research: planning, conducting, and evaluating quantitative and qualitative research (4. Bs.). Boston: Pearson

Dellinger, A. B., Bobbett, J. J., Olivier, D. F., \& Ellett, C. D. (2008). Measuring teachers' self-efficacy beliefs: development and use of the TEBS-Self. Teaching and Teacher Education, 24(3), 751-766 https://doi.org/10.1016/j.tate.2007.02.010

Dimitriou, A. \& Christidou, V. (2007). Pupils' understanding of air pollution, Journal of Biological Education, 42(1), 24-29. https://doi.org/10.1080/00219266.2007.9656103

Dinsinger, J. F., \& Roth, C. E. (1998). Environmental literacy. ERIC/CSMEE digest (Colombus, OH, ERIC Clearinghouse for Science, Mathematics and Environmental Education, ED 351201).

Driver, R., Asoko, H., Leach, J., Scott, P., \& Mortimer, E. (1994). Constructing scientific knowledge in the classroom. Educational Researcher, 23(7), 5-12. https://doi.org/10.3102/0013189X023007005

Ekici, G. (2014). Views of teachers on responsibility perceptions about students' academic achievement and failure: the case of pre-service teachers of biology. Elementary Education Online, 13(4), 1414-1448.

Fien, J. (1993). Education for the environment: critical curriculum theorizing and environmental education geelong: Deakin University Press

Flogaitis, E., \& Agelidou, E. (2003). Kindergarten teachers' conceptions about nature and the environment, Environmental Education Research, 9(4), 461-478. https://doi.org/10.1080/1350462032000126113

Gardner, C. C. (2009). Self-efficacy in environmental education: experiences of elementary education preservice teachers. Unpublished Mastery Thesis. University of South Carolina, USA.

Georgopoulos, A., Mpirmpili, M., \& Dimitriou, A. (2011). Environmental education (EE) and experiential education: a promising "marriage" for Greek pre-school teachers, Creative Education, 2(2), 114-120. https://doi.org/10.4236/ce.2011.22016

Greer, M., Richardson, L., Liang, L., \& Donna, G. W. (2014). Examining the durability of environmental education 
self-efficacy beliefs in preservice teaching, Applied Environmental Education \& Communication, 13(1), 38-47. https://doi.org/10.1080/1533015X.2014.913963

Henson, R. K. (2001). Relationships between pre-service teachers' self-efficacy, task analysis and classroom management beliefs. Paper presented at the annual meeting of the Southwest Educational Research Association, New Orleans.

Hogan, K. (2002). Small groups' ecological reasoning while making an environmental management decesion. Journal of Research in Science Teaching, 39, 341-368. https://doi.org/10.1002/tea.10025

Holden, M. E., Groulx, J., Bloom, M., \& Weinberg, M. H. (2011). Assessing teacher self-efficacy through an outdoor professional development experience. Electronic Journal of Science Education, 12(2), 1-25.

Hungerford, H. R., \& Peyton, R. B. (1994). Procedures for Developing an Environmental Education Curriculum: A Discussion Guide for UNESCO Training Seminars on Environmental Education, Environmental Education Series 22, Paris.

Intergovernmental Panel On Climate Change (IPCC). (2014). Climate Change 2014-Impacts, Adaptation and Vulnerability. Contribution of Working Group II to The Fifth Assessment Report of The IPCC Cambridge. Cambridge University.

Jimenez, A. M. P., \& Puig, B. (2011, September). The role of justification in integrating evidence in arguments: making sense of gene expression. Paper presented in the Esera Meeting, LYON.

Jimenez-Aleixandre, M. P., \& Pereiro-Munaz, C. (2002). Knowledge producers or knowledge consumers? argumentation and decision making about environmental management. International Journal of Science Education, 24, 1171-1190. https://doi.org/10.1080/09500690210134857

Kalogiannakis, M., \& Papadakis, S. (2017). Combining mobile technologies in environmental education: A Greek case study. International Journal of Mobile Learning and Organization, 11(2), 108-128 https://doi.org/10.1504/IJMLO.2017.084272

Kurt, H., \& Ekici, G. (2013). An analysis of the effect of classroom management course on responsibility perception of student teachers for student achievement. International Journal of Social Science, 6(8), 901-939.

Kurt, H., Gökmen, A., \& Ekici, G. (2014). Determination of cognitive structures of teacher candidates on computer concept. Gazi University Journal of Gazi Education Faculty, 34(3), 357-401.

Mcmichael, A. J., Woodruff, R. E., \& Hales, S. (2006). Climate change and human health: present and future risks. The Lancet, 367, 859-869. https://doi.org/10.1016/S0140-6736(06)68079-3

Miles, M. B., \& Huberman, A. M. (1994). Qualitative data analysis: an expanded sourcebook, 2nd Ed., Sage Publications, Newbury Park, CA, 1994.

Moseley, C., \& Utley, J. (2008). An exploratory study of preservice teachers' beliefs about the environment. Journal of Environmental Education, 39(4), 15-29. https://doi.org/10.3200/JOEE.39.4.15-30

Moseley, C., Reinke, K., \& Bookout, V. (2002). The effect of teaching outdoor environmental education on preservice teachers' attitudes toward self-efficacy and outcome expectancy. Journal of Environmental Education, 34(1), 9-15. https://doi.org/10.1080/00958960209603476

Newell, R., \& Dale, A. (2015). Meeting The Climate Change Challenge (MC3): The role of the internet in climate change research dissemination and knowledge mobilization. Environmental Communication, 9(2), 208-227. https://doi.org/10.1080/17524032.2014.993412

Newton, P., Driver, R., \& Osborne, J. (1999). The place of argumentation in the pedagogy of school science. International Journal of Science Education, 21(5), 553-576. https://doi.org/10.1080/095006999290570

North American Association for Environmental Education [NAAEE]. (2010). Guidelines for The Preparation and Professional Development of Environmental Educators. Washington, DC: NAAEE.

Orr, D. (1994). Earth in mind: on education, environment, and the human prospect Washington, D.C.: Island Press.

Özdemir, A. (2003). Investigation of Environmental Knowledge and Consciousness of Primary Eighth Grade Students. Unpublished Doctorate Thesis, Dokuz Eylül University Educational Sciences Institute, Izmir

Özdemir, A., Aydın, N., \& Vural, R. (2009). A scale development study on self-efficacy belıefs through environmental education. Journal of Dokuz Eylül University, 26, 1-8.

Özer, U. (1991). Environmental philosophy within the relationships of humanity, environment, culture and economy. 
Man and the Environment Conference Proceedings, 1, 318-321.

Özkan, Ö., Tekkaya, C., \& Çakıroğlu, J. (2002). Preservice science teachers' levels of understanding science concepts, attitudes towards science education and self-efficacy beliefs. V. Science and Mathematics Congress, Middle East Technical University, Ankara.

Roth, C. E. (1992). Environmental literacy: its roots, evolution and directions in the 1990s. Columbus, OH: ERIC/SMEAC Information Reference Center.

Saidi, K., \& Hammami, S. (2015). The impact of CO2 emissions and economic growth on energy consumption in 58 countries. Energy Reports, 1, 62-70. https://doi.org/10.1016/j.egyr.2015.01.003

Sauvé, L. (1996). Environmental education and sustainable development: a further appraisal. Canadian Journal of Environmental Education (CJEE), 1(1), 7-34.

Savran, A., \& Çakiroğlu, J. (2003). Differences Between elementary and secondary preservice science teachers' perceived efficacy beliefs and their classroom management beliefs. TOJET, 2(4), 15-20.

Sia, A. P. (1992). Preservice elementary teachers' perceived efficacy in teaching environmental education: A preliminary study. East Lansing, MI: National Center for Research on Teacher Learning. (ERIC Document Reproduction Service No. ED362487)

Sia, A. P. (1992). Preservice Elementary Teachers' Perceived Efficacy in Teaching Environmental Education: A Preliminary Study. Paper Presented at The North American Association for Environmental Education Annual Conference, Toronto, ON. (Must be removed)

Simon, S., Erduran, S., \& Osborne, J. (2006). Learning to teach argumentation: research and development in the science classroom. International Journal of Science Education, 28(2-3), 235-260. https://doi.org/10.1080/09500690500336957

Smolleck, L. D., Zembal-Saul, C., \& Yoder, E. P. (2006). The development and validation of an instrument to measure preservice teachers' self-efficacy in regard to the teaching of science an inquiry. Journal of Science Teacher Education, 17, 137-163. https://doi.org/10.1007/s10972-006-9015-6

Sözer, E. (1991). Effectiveness of teacher training systems on teacher behavior in Turkish universities. Eskisehir: Anadolu University Printing House

Toulmin, S. (1958). The uses of argument. Cambridge: Cambridge University Press

Trauth-Nare, A. (2015). Influence of an intensive, field-based life science course on preservice teachers' self-efficacy for environmental science teaching. J. Sci. Teacher Educ. (2015), 26, 497-519. https://doi.org/10.1007/s10972-015-9434-3

Tschannen-Moran, M., \& Hoy, A. W. (2007). The differential antecedents of self-efficacy beliefs of novice and experienced teachers, Teaching and Teacher Education, 23, 944-956. https://doi.org/10.1016/j.tate.2006.05.003

Tschannen-Moran, M., \& Woolfolk, H. A. (2001). Teacher efficacy: capturing and elusive construct. Teaching and Teacher Education, 17, 783-805. https://doi.org/10.1016/S0742-051X(01)00036-1

Whitehead, J., \& Mcniff, J. (2004). Action research living theory. London: Sage.

Woolfolk, A. E., \& Hoy, W. K. (1990). Prospective teachers' sense of efficacy and beliefs about control. Journal of Educational Psychology, 82(1), 81-91. https://doi.org/10.1037/0022-0663.82.1.81

Yılmaz, M., Gerçek, C., Köseoğlu, P., \& Soran, H. (2006). An analysis of the self -efficacy beliefs about computers of the biology student teachers in hacettepe university. Hacettepe University Journal of Education, 30, $278-287$.

Yılmaz, M., Yıldız, K., \& Sipahioğlu, Ş. (2005). Environmental science and education, Gündüz Education and Publishing.

Yin, Y., Mizokami, S., \& Aikawa, K. (2015). Compact development and energy consumption: scenario analysis of urban structures based on behavior simulation. Applied Energy, 159, 449-457. https://doi.org/10.1016/j.apenergy.2015.09.005

\section{Copyrights}

Copyright for this article is retained by the author(s), with first publication rights granted to the journal.

This is an open-access article distributed under the terms and conditions of the Creative Commons Attribution license which permits unrestricted use, distribution, and reproduction in any medium, provided the original work is properly cited. 